\title{
Pemberdayaan Wanita Tani dalam Budidaya Kedelai Varietas Unggul Bahan Baku Pembuatan Tahu
}

\author{
Erni Suminar ${ }^{1}$, Wieny H. R. Marma Jaya ${ }^{2}$, Rani Andriani Budi Kusumo ${ }^{3}$, \\ Syariful Mubarok ${ }^{4}$ \\ 1, 2,3,4 Universitas Padjadjaran
}

\begin{tabular}{|c|c|}
\hline ARTICLE INFO & ABSTRACT \\
\hline $\begin{array}{l}\text { Article History: } \\
\text { Received 01.06.2018 } \\
\text { Received in revised } \\
\text { form } 10.06 .2018 \\
\text { Accepted } 27.06 .2018 \\
\text { Available online } \\
\text { 30.06.2018 }\end{array}$ & $\begin{array}{l}\text { Soybean is one of the important crops containing high protein content. The } \\
\text { demand of soybean increases from year to year, because the domestic } \\
\text { production could not reach the market demand and it is still imported. } \\
\text { Therefore, the necessary effort to increase soybean production must be done } \\
\text { such as by expanding the planting area, planting superior varieties especially } \\
\text { for raw materials of tofu, and the cultivation techniques. Sumedang is one of } \\
\text { the centers of tofu production in West Java that has the suitable agro-climatic } \\
\text { conditions for soybeanproduction as a raw material. Some of the farm } \\
\text { communities have cultivated soybeans, however they still needs the efforts to } \\
\text { increase the soybean production especially for the types of soybean for raw } \\
\text { material of tofu production. The aim of IbM activity is to socialize and make a } \\
\text { pilot demonstration plot of some of superior soybean varieties for tofu } \\
\text { production in Sumedang. The results of these activities include: (1) the } \\
\text { demonstration plots of soybean varieties, (2) producing the high seed quality of } \\
\text { superior soybean varieties, (3) improving skill and knowledge of farmers in the } \\
\text { cultivation of superior soybean varieties and also pest and disease control, (4) } \\
\text { obtaining the samples of tofu from superior soybean varieties grown in partner } \\
\text { locations. }\end{array}$ \\
\hline & Keywords: Seed production, Soybean, Tofu. \\
\hline
\end{tabular}

DOI: $10.30653 / 002.201831 .46$

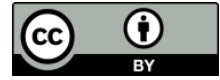

This is an open access article distributed under the terms of the Creative Commons Attribution 4.0 International License, which permits unrestricted use, distribution, and reproduction in any medium, provided the original work is properly cited. ๑ 2018 Emi Suminar, Wieny H. R. Marma Jaya, Rani Andriani Budi Kusumo, Syariful Mubarok.

\section{PENDAHULUAN}

Kedelai merupakan salah satu komoditas penting di Indonesia, karena kedelai merupakan salah satu bahan baku utama untuk industri pangan seperti tahu, tempe, kecap, susu kedelai, tauco, dan makanan olahan lainnya, namun hingga saat ini kebutuhan belum dapat terpenuhi dari produksi dalam negeri. Pada tahun 2013 jumlah produksi kedelai sebanyak 807.568 ton dan luas lahan produksi sebesar 554.132 ha (BPS, 2013). Dilihat dari data jumlah produksi dan luas lahan diatas Indonesia masih tergolong

${ }^{1}$ Corresponding author's address: Program Studi Agroteknologi Fakultas Pertanian Universitas Padjadjaran Bandung; Jl. Raya Bandung-Jatinangor km 21 Bandung 40600. Email: erni.suminar@unpad.ac.id. 
jauh lebih rendah jika dibandingkan dengan negara maju, karena dari urutan dua puluh sembilan negara yang ada Indonesia menduduki peringkat ke dua puluh delapan (FAOSTAT, 2012). Peningkatan kebutuhan kedelai di Indonesia akan terus meningkat sejalan dengan meningkatnya permintaan konsumen terutama konsumen pengrajin tahu dan tempe.

Produksi kedelai di Indonesia yang semakin menurun jumlahnya dari tahun ke tahun disebabkan antara lain yaitu (Ditjentan, 2004 diacu Sudaryanto \& Swastika 2016): (1) produktivitas yang masih rendah, sehingga kurang menguntungkan dibandingkan komoditas pesaing lainnya, (2) belum berkembangnya industri perbenihan, (3) keterampilan petani yang masih rendah, (4) adanya gangguan dari organisme pengganggu tanaman (OPT), (5) belum berkembangnya pola kemitraan, karena sektor swasta belum tertarik untuk melakukan agribisnis kedelai dan (5) kebijakan perdagangan bebas (bebas tarif impor), sehingga harga kedelai impor lebih murah dari kedelai produksi dalam negeri.

Pemerintah melalui Kementerian Perdagangan pada tahun 2013 menghapus bea masuk kedelai impor (Kementerian Perdagangan, 2015). Kondisi ini menyebabkan ketergantungan Indonesia akan impor semakin meningkat, hal tersebut tidak dapat dibiarkan terus menerus mengingat potensi pengembangan kedelai di Indonesia sangat terbuka dengan semakin banyaknya varietas unggul yang memiliki kualitas lebih baik dibandingkan dengan kedelai impor serta ketersediaan lahan yang potensial di Indonesia.

Kurangnya stok bahan baku pembuatan tahu dan tempe terjadi karena masih kurangnya minat masyarakat untuk menanam kedelai dibandingkan dengan komoditas lainnya, selain itu juga keterbatasan lahan dan ketersediaan benih unggul masih terbatas sehingga menjadi kendala besar bagi petani untuk membudidayakan tanaman ini, selain itu juga rendahnya produktivitas kedelai di Indonesia disebabkan oleh beberapa faktor diantaranya serangan hama dan patogen selama masa produksi di lapangan serta adanya cekaman lingkungan fisik di areal pertanaman sehingga untuk meningkatkan produksi kedelai diperlukan kultivar-kultivar yang mampu memberikan hasil tinggi disamping memiliki sifat yang toleran terhadap berbagai patogen serta cekaman lingkungan di lapangan.

Saat ini sudah banyak varietas-varietas unggul kedelai yang dilepas oleh kementerian namun ketersediaan benih di pasaran masih sangat rendah sehingga masih banyak masyarakat khususnya di Jawa Barat menjadikan kedelai-kedelai tersebut masih belum dikenal oleh masyarakat luas sehingga perlu dilakukan pengadaan benih kedelai berkualitas dalam jumlah banyak sehingga proses diseminasi dan penanaman kedelai varietas unggul dapat segera dilakukan. Kebutuhan benih diprediksi tahun 2014 sekitar 73.200 ton (Direktorat Jenderal Tanaman Pangan, 2012), hal ini menjadikan penyediaan benih unggul bermutu yang toleran terhadap cekaman biotik dan abiotik menjadi persyaratan utama untuk perluasan areal kedelai. Upaya adaptasi perubahan iklim untuk tanaman pangan salah satunya dapat dilakukan dengan pengembangan jenis dan varietas tanaman yang toleran terhadap stres lingkungan, namun benih varietas unggul yang dihasilkan oleh pemulia tanaman yang masih dalam jumlah yang terbatas.

Untuk mengatasi masih rendahnya produktivitas kedelai, diperlukan penggunaan kultivar unggul serta perluasan ke lahan sub-optimal seperti lahan kering masam, lahan pasang surut dan lahan kering masam sekitar 102,8 juta ha dan 23,1 juta ha lahan pasang surut (Mulyani et al, 2010). 
Swasembada kedelai dapat dicapai apabila luas panen mencapai 2,5 juta ha atau 3,5 juta ha termasuk kebutuhan kedelai untuk pakan ternak hal ini dapat dilakukan dengan membuka lahan baru khusus untuk kedelai secara bertahap mencapai 1.000.000 ha dari potensi lahan yang disebutkan tersedia 7,2 juta ha (Sumarno 2011). Salah satu alternatif yang dapat dilakukan untuk peningkatan produksi kedelai adalah dengan memperluas penanaman kedelai-kedelai varietas unggul terutama yang memiliki kriteria untuk para pembuat tahu.

Berdasarkan data monografi desa tercatat bahwa Desa Wanasari Kecamatan Surian, Kabupaten Sumedang merupakan daerah yang potensial untuk penanaman kedelai varietas unggul dengan memanfaatkan lahan-lahan sawah. Sebagian besar penduduknya bermata pencaharian $78 \%$ sebagai petani dengan penggarapan lahan kedelai seluas 20 ha dengan produksi 28 ton. Jika dibandingkan dengan produktivitas kedelai varietas unggul yang dapat mencapai 2,86 s.d 4,1 ton per ha. Keberadaan Kelompok Wanita Tani di desa tersebut yang akan dijadikan sebagai mitra untuk pelaksanaan kegiatan ini, diharapkan dari hasil pertanaman kedelai yang penjualannya bermitra dengan produsen tahu di Sumedang diharapkan dapat meningkatkan taraf hidup dan kesejahteraan masyarakat setempat.

Kedelai varietas unggul merupakan komoditas potensial dan memiliki keunggulan dibandingkan dengan kedelai impor memungkinkan pemasarannya sangat menjanjikan bagi Kelompok Wanita Tani yang terlibat kegiatan ini. Berdasarkan kesepakatan bersama mitra, bahwa mitra memiliki keinginan untuk menanam tanaman kedelai varietas unggul bahan baku tahu yang sangat dibutuhkan oleh produsen tahu khususnya daerah Sumedang.

Tujuan dari kegiatan ini adalah: 1) Menambah wawasan mitra tentang prospek pengembangan benih kedelai varietas unggul; 2) Menambah wawasan dan keterampilan mitra untuk dapat memproduksi kedelai baik untuk memenuhi kebutuhan konsumsi maupun untuk penyediaan benih;3) Menambah wawasan dan keterampilan mitra dalam budidaya kedelai; 4) Membangun kepercayaan masyarakat agar berminat untuk menggunakan kedelai unggul lokal daripada kedelai impor; dan 5) Memberikan informasi prosedur menghasilkan benih bersertifikat

Hasil kegiatan ini diharapkan dapat terwujudnya: 1) Lahan pertanaman kedelai varietas unggul di wilayah tersebut; 2) Menjadikan kelompok wanita tani mitra dapat melakukan penangkaran benih kedelai berkualitas; 3) Diperolehnya paket teknologi budidaya kedelai varietas unggul bahan baku pembuatan tahu; 4) Diperolehnya teknologi pengendalian hama dan penyakit tanaman kedelai bahan baku tahu; dan 5) Diperolehnya produk tahu dari berbagai varietas kedelai unggul sebagai bahan baku tahu agar dikenal masyarakat luas khususnya petani dan perajin tahu kawasan Sumedang.

\section{METODE PELAKSANAAN}

Metode kegiatan terdiri dari tiga tahap: 1) tahap pra-kegiatan; 2) tahap pelaksanaan; dan 3) evaluasi. Tahap pra-kegiatan merupakan tahap penjajagan dengan melakukan observasi dan wawancara dengan mitra terkait penanaman kedelai. Tahap pelaksanaan merupakan kegiatan lapangan yang terdiri empat kegiatan: a) Penyuluhan, b) Pembuatan Demplot Percontohan Produksi di Lapangan, c) Perhitungan analisis usaha tani, d) Pelatihan pembuatan tahu berbahan baku varietas unggul yang ditanam di lokasi mitra. 
Tahap evaluasi merupakan kegiatan untuk mengukur sejauh mana keberhasilan program, bagaimana kendala-kendala yang dihadapi selama program berjalan.

\section{HASIL DAN PEMBAHASAN}

\section{Penjajagan}

Berdasarkan hasil penjajagan dan wawancara yang dilakukan dengan mitra tentang pertanaman kedelai, sebagian besar pernah melakukan budidaya kedelai namun permasalahan di lapangan yang sering dihadapi seperti daya tumbuh dan produktivitas yang rendah, serangan hama dan penyakit, kurangnya ketersediaan benih unggul, hasil yang dirasakan kurang menguntungkan, serta pemasaran yang masih dihargai rendah. Selama ini, pertanaman kedelai masih dibudidayakan secara asalan, sehingga hasil yang diperoleh sangat rendah tetapi biaya produksi yang masih tinggi.

Faktor lainnya, mitra masih sulit mendapatkan benih kedelai unggul yang potensi hasil tinggi dan berkualitas. Mitra banyak menggunakan benih kedelai yang ada dan kadang-kadang sudah disimpan dalam waktu lama dengan kondisi penyimpanan benih seadanya sehingga kemungkinan benih yang digunakan sudah kehilangan viabilitas/daya tumbuh rendah. Saat ini, varietas yang sudah dikenal di masyarakat diantaranya varietas Wilis, sedangkan varietas yang disosialisasikan pada kegiatan IbM ini merupakan varietas-varietas baru yang memiliki prospek pemasaran yang baik terutama untuk memasok kebutuhan kedelai para perajin tahu di Sumedang. Beberapa varietas yang diperkenalkan diantaranya Varietas Mutiara1, Var. Gepak Kuning, Var. Argomulyo, dan Varietas Dering1.

Varietas Mutiara1 merupakan hasil mutasi gen pada kedelai lokal varietas Muria. Varietas ini telah dilepas berdasarkan Surat Keputusan Menteri Pertanian Nomor: 2602/Kpts/SR.120/7/2010 tentang Pelepasan Galur Mutan Kedelai 37 MBB sebagai Varietas Unggul dengan nama Mutiara1. Keunggulan varietas Mutiara1 adalah: (i) umurnya genjah, yang dapat dipanen pada umur 82 hari, (ii) pada usia 30 hari sudah berbunga warna ungu, (iii) berbiji besar, (iv) tahan penyakit karat daun (Phakospora pachirhyzi Syd) dan tahan terhadap penyakit bercak atau hawar daun cokelat (Cercospora), dan juga tahan hama penggerek pucuk (Melanagromyza sojae), dan (v) produktivitas 2,4 ton hingga 4,1 ton per hektar (Pawiroharsono, 2012, pp. 669-670). Kedelai varietas Mutiara1 ini merupakan kedelai super jumbo yang sangat cocok digunakan sebagai bahan baku dalam industri pembuatan tempe dan tahu.

Varietas Argomulyo memiliki biji besar dan berwarna kuning. Dalam evaluasi preferensi beberapa varietas unggul kedelai terungkap bahwa varietas Argomulyo menduduki urutan tertinggi dari aspek tekstur, penampakan, dan hasil untuk industri tempe dan tahu. Untuk industri susu, varietas Argomulyo menghasilkan kadar pati tinggi tetapi rasa susu agak "langu" (Krisdiana, 2007, p. 124). Varietas Dering1 memiliki sifat toleran kekeringan selama fase reproduktif, dengan tingkat cekaman setara kadar air tanah pF 2,7-4,2 pada kedalaman tanah 0-20 cm. Selama pengujian, varietas Dering1 dalam kondisi relatif kekeringan mampu memberi hasil rata-rata 1,95 ton per hektar dengan potensi hasil 2,83 ton per hektar, umur masak 81 hari, dan bobot biji 10,7 gram per 100 biji, tahan hama penggerek polong dan penyakit karat daun. Varietas Dering1 sesuai ditanam di lahan sawah pada MK I dan MK II, serta lahan tegal pada MK I atau lahan dengan irigasi terbatas (Balitbang Pertanian, 2014), dan Varietas Gepak Kuning memiliki sifat Agak tahan terhadap ulat grayak dan Aphis sp, penggulung daun, Phedonia sp., kadar 
rendemen tahu tinggi, beradaptasi baik di lahan sawah dan tegal baik pada musim hujan maupun kemarau (Balitbang Pertanian, 2014).

Untuk mensosialisasikan varietas-varietas unggul serta mengatasi permasalahan ini, maka dilakukan kegiatan penyuluhan dengan harapan dapat memberikan informasi agar program pengembangan pertanaman kedelai di desa mitra dapat terlaksana dengan baik. Materi yang disampaikan pada kegiatan ini, meliputi: (1) Produksi, Pengolahan dan Penyimpanan Benih Kedelai Varietas Unggul, (2) Pengenalan Berbagai Varietas Kedelai Unggul dan Manfaatnya serta Budidaya dan Penanganan Pasca Panen, (3) Prosedur Produksi dan Sertifikasi Benih Kedelai “, (4) Praktik Budidaya Tanaman Yang Baik (Good Agriculture Practices) Kedelai Tropis", (5) Perhitungan Analisis Usahatani Produksi Kedelai untuk Konsumsi dan Perbenihan. Hasil evaluasi peserta sebelum kegiatan penyuluhan berlangsung, dapat dilihat pada Gambar 1.

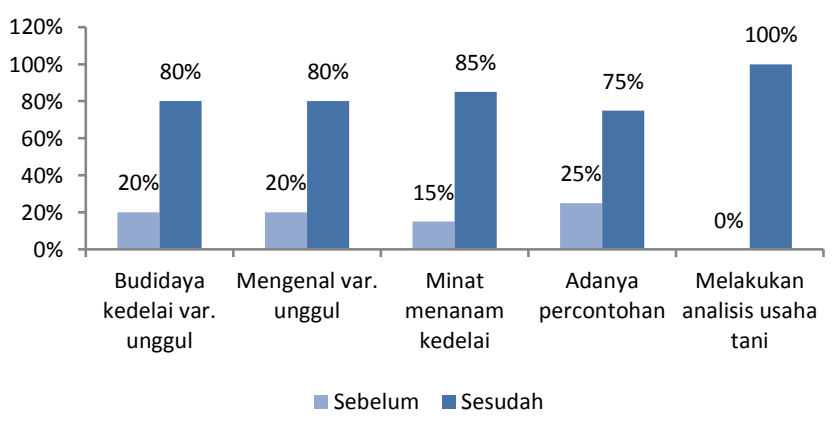

\section{Gambar 1. Hasil Rekapitulasi Pengisian Kuosioner Peserta Awal Kegiatan}

Gambar 1 menunjukkan bahwa informasi mengenai varietas unggul dan ketersediaan benihnya masih sangat minim bahkan mitra baru sekitar $20 \%$ yang pernah melakukan penanaman varietas unggul dan kurangnya minat dari mitra untuk membudidayakan kedelai. Setelah kegiatan penyuluhan berlangsung akan dilakukan praktik secara langsung di lapangan dengan pendampingan dari Tim IbM yang bekerjasama dengan Tim Lapangan para Penyuluh Dinas Pertanian Kabupaten Sumedang yang ditempatkan di lokasi mitra.

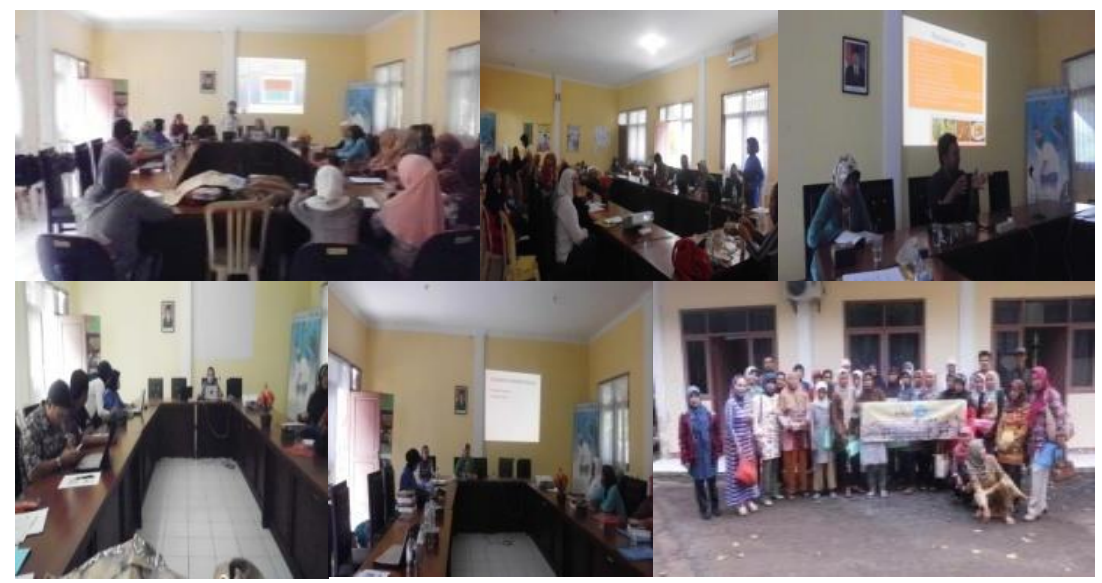

Gambar 2. Dokumentasi Kegiatan Penyuluhan

Kegiatan ini diharapkan dapat dijadikan sebagai percontohan dengan melihat pertumbuhan dan potensi hasil beberapa varietas kedelai unggul di daerah tersebut, 
selain itu kedelai yang dihasilkan dari kerjasama dengan mitra kelompok wanita tani ini dapat dijadikan sebagai benih sumber untuk kegiatan budidaya selanjutnya.

Kegiatan penyuluhan dihadiri oleh 28 orang peserta yang terdiri dari 20 orang mitra, perwakilan pengurus $\mathrm{PKK}$, aparat desa, instansi badan ketahanan pangan, serta penyuluh yang bertugas di desa mitra serta perwakilan dari kelompok tani lainnya (Gambar 2). Kegiatan ini diharapkan dapat dijadikan sebagai percontohan dengan melihat pertumbuhan dan potensi hasil beberapa varietas kedelai unggul di daerah tersebut, selain itu kedelai yang dihasilkan dari kerjasama dengan mitra kelompok wanita tani ini dapat dijadikan sebagai benih sumber untuk kegiatan budidaya selanjutnya.

Pada saat bersamaan, mitra diberi polibag dan benih-benih kedelai varietas unggul tersebut untuk ditanam pada kegiatan praktik langsung di halaman rumah dan di lahan demplot percontohan milik mitra. Mitra sangat antusias untuk kembali mencoba membudidayakan kedelai varietas unggul yang memiliki prospek yang cukup menguntungkan.

\section{Kegiatan Lapangan}

Setelah mengikuti kegiatan penyuluhan, mitra melakukan praktik langsung di lapangan. Kegiatan ini diawali dengan persiapan lahan yang akan digunakan untuk pembuatan demplot (Gambar 3).

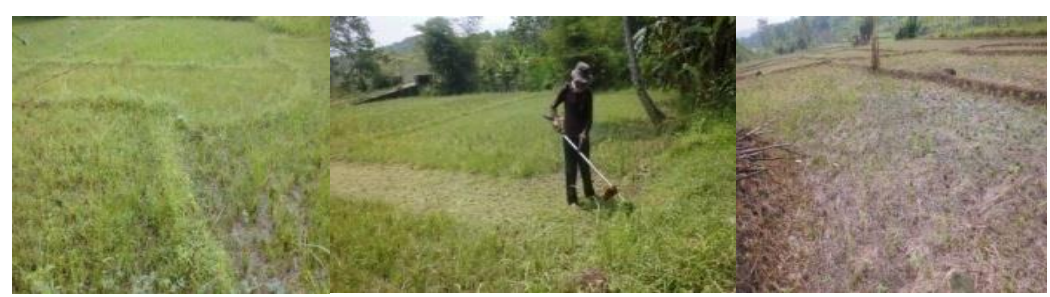

Gambar 3. Persiapan Lahan

Kegiatan penanaman benih keempat varietas kedelai (Gepak Kuning, Mutiara1, Argomulyo, dan Dering1) dilakukan dengan melibatkan semua mitra kelompok wanita tani dan tim penyuluh lapangan daerah mitra (Gambar 4).

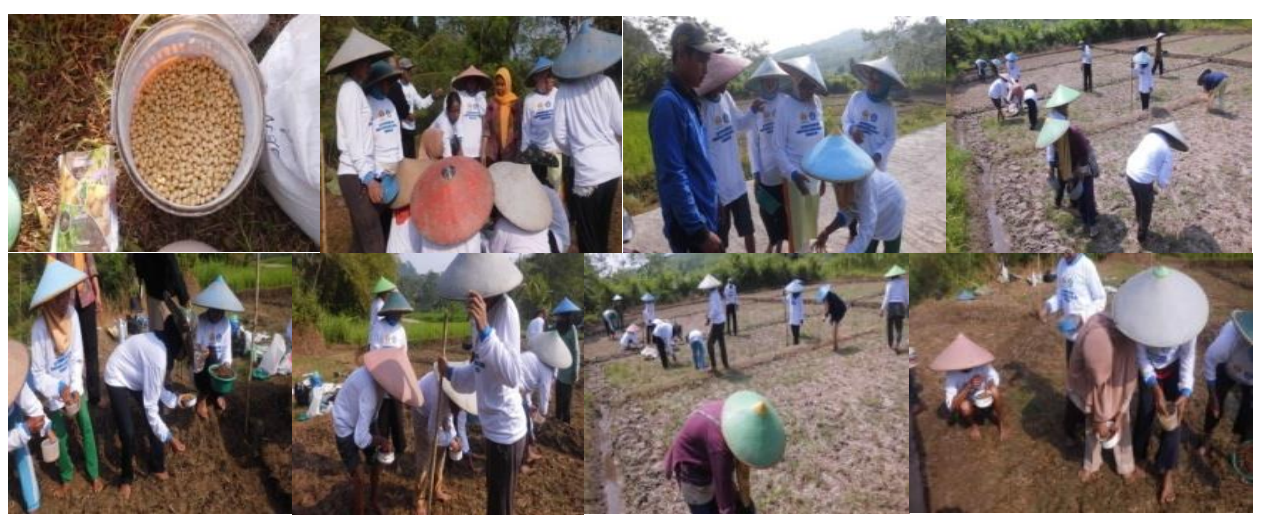

Gambar 4. Kegiatan Penanaman di Lapangan

Penanaman kedelai juga dilakukan oleh mitra di dalam polibag yang disimpan di halaman rumah masing-masing mitra seperti yang terlihat pada Gambar 5. 


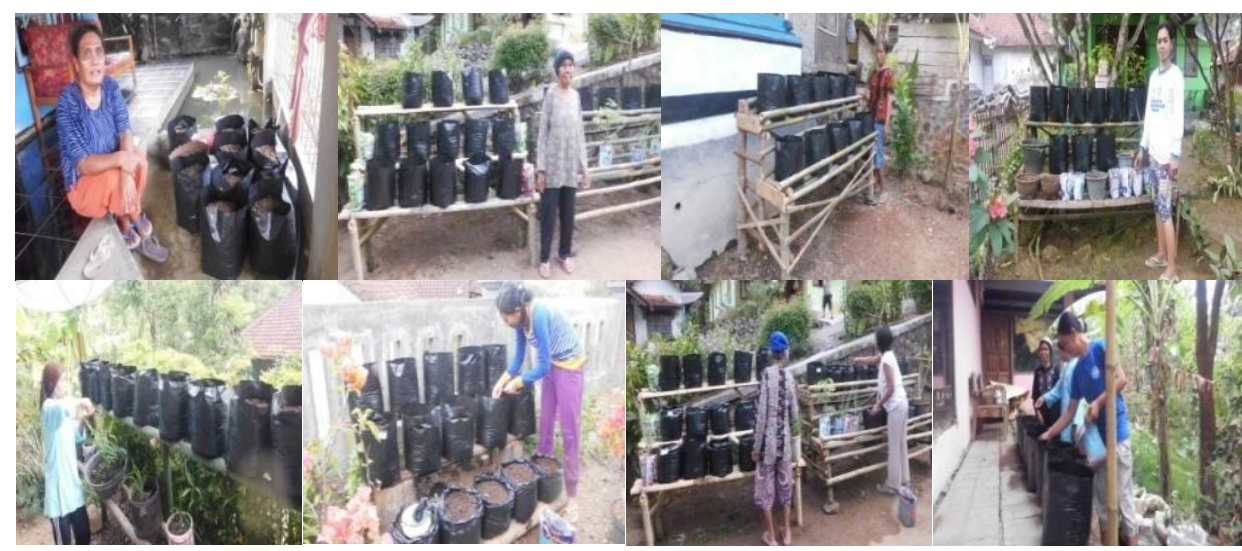

Gambar 5. Penanaman Kedelai di Polibag

\section{Evaluasi Hasil Kegiatan}

Berdasarkan hasil kegiatan di lapangan diperoleh data telah terjadi perubahan sikap mitra terhadap budidaya kedelai yang dapat dilihat pada Gambar 6 .

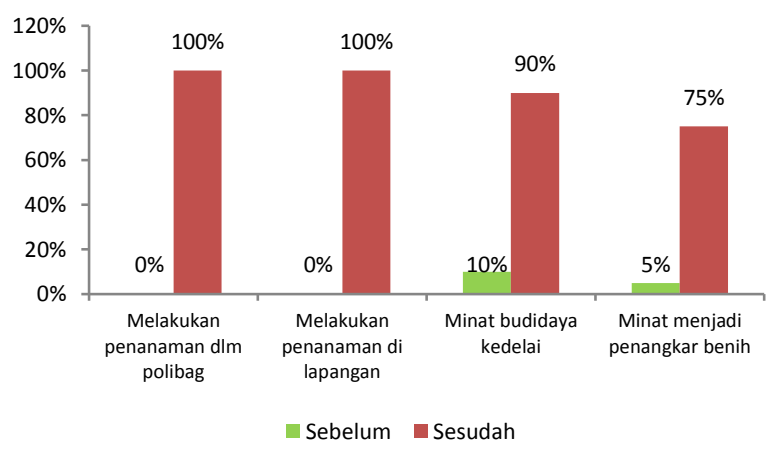

Gambar 6. Diagram Perubahan Setelah Kegiatan

Hasil kegiatan dapat dilihat dengan mulai berkembangnya pertanaman kedelai varietas-varietas unggul baru yang selama ini belum dikenal oleh masyarakat setempat. Mitra secara bersama-sama melakukan penanaman serempak baik di lapangan maupun di polibag dengan perawatan oleh masing-masing mitra. Kegiatan yang dilakukan oleh mitra dalam hal pemeliharaan tanaman dilakukan secara intensif dan bergantian dengan data keterlibatan mitra yang dpata dilihat pada Gambar 7.

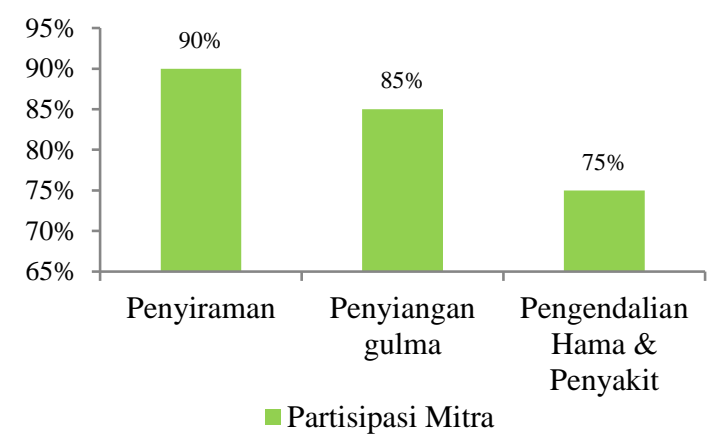

Gambar 7. Partisipasi Mitra dalam Kegiatan Pemeliharaan Tanaman Kedelai 
Mitra turut berpartisipasi dalam kegiatan penyiangan yang dilakukan secara berkala yang dapat dilihat pada Gambar 8.

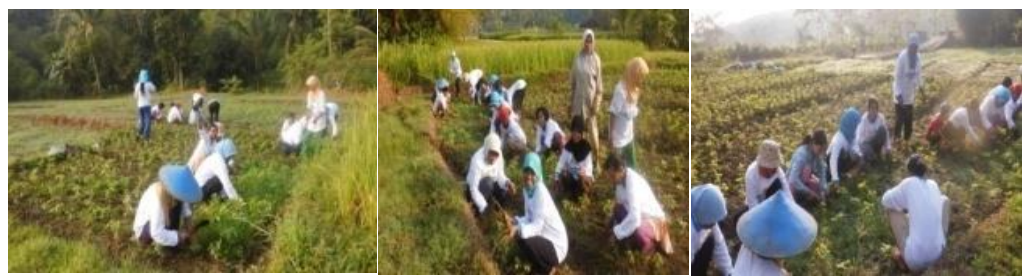

Gambar 8. Partisipasi Mitra dalam Kegiatan Pemeliharaan Tanaman

Kondisi pertumbuhan tanaman kedelai dan evaluasi hasil pertanaman mitra di lapangan dapat dilihat pada Gambar 9.

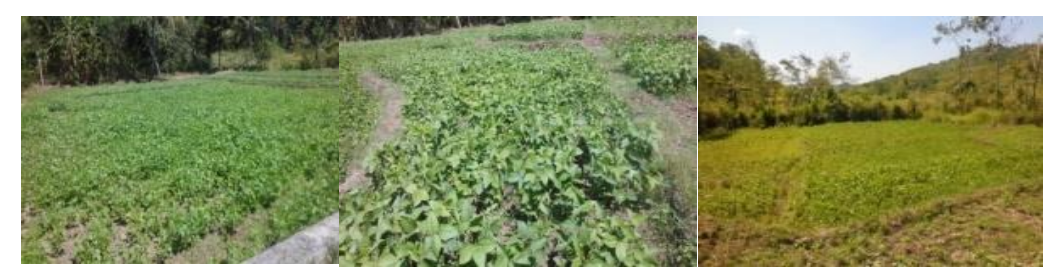

Gepak Kuning Argomulyo Mutiara1

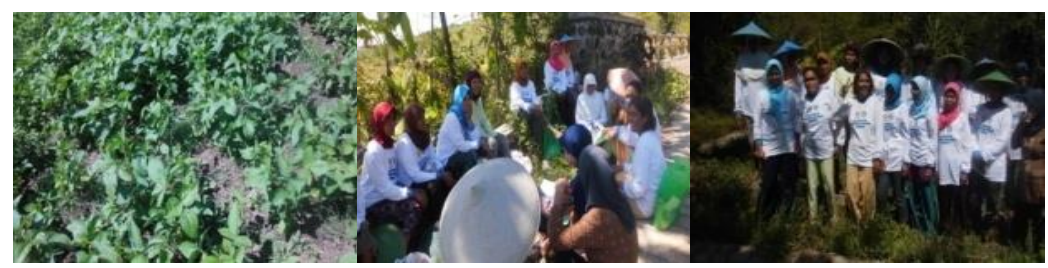

Dering1

Kegiatan Evaluasi

Gambar 9. Kondisi Pertanaman Kedelai Milik Mitra di Lapangan

\section{Pemanenan}

Pertanaman kedelai yang ditanam oleh mitra 100\% berhasil membentuk polong dan kegiatan panen dilakukan oleh mitra seperti yang terlihat pada Gambar 10.

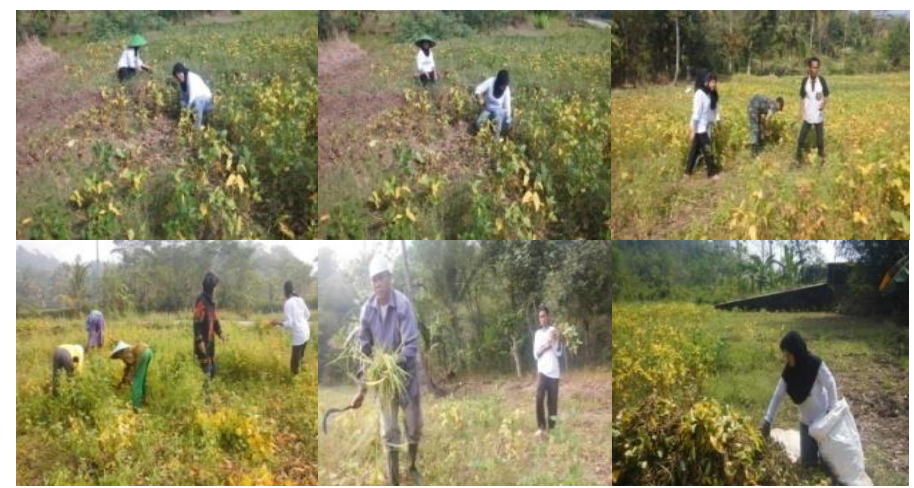

Gambar 10. Kegiatan Panen oleh Mitra

\section{Pengolahan Hasil Panen}

Hasil pertanaman yang telah dipanen kemudian dilakukan pengolahan agar dapat digunakan baik untuk kebutuhan konsumsi maupun untuk dijadikan benih pada musim tanam berikutnya. Setelah kegiatan panen, dilakukan penjemuran dengan tujuan untuk 
menurunkan kadar air polong yang dihasilkan sehingga dapat diproses dan disimpan pada kondisi yang aman. Kegiatan ini dapat dilihat pada Gambar 11.

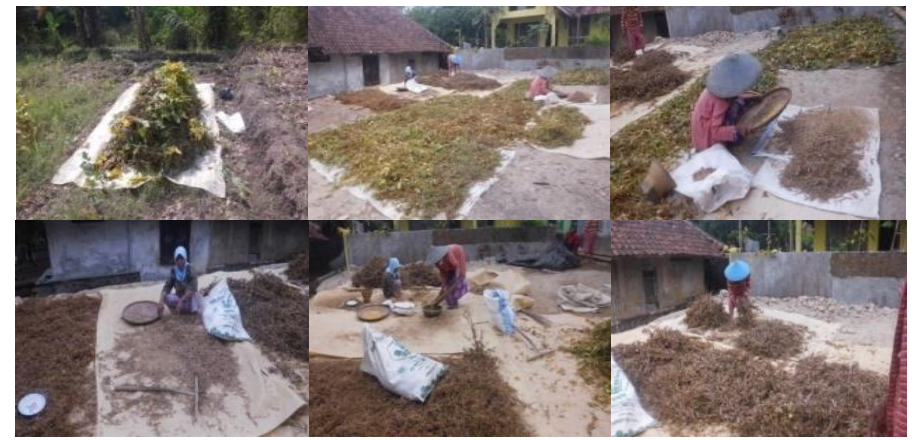

Gambar 11. Pengolahan Hasil Panen oleh Mitra

\section{Pengujian Laboratorium}

Mutu benih merupakan faktor penentu keberhasilan penanaman secara ekonomis dan mutu benih yang tinggi salah satunya dicirikan dengan daya berkecambah benih tinggi (Ilyas, 2012). Prinsip dari pengujian daya berkecambah adalah menguji sejumlah benih dan menentukan persentase dari jumlah benih tersebut yang dapat tumbuh atau mampu berkecambah secara normal pada jangka waktu yang telah ditentukan (Elfiani \& Jakoni, 2015).

Pengujian laboratorium pada kegiatan ini dilakukan untuk menghitung daya kecambah benih yang dihasilkan, tetapi sebelumnya dilakukan pembersihan dari sisa-sisa kotoran, biji gulma, batu kerikil yang tercampur dengan benih setelah pemanenan dan pengeringan (Gambar 12).

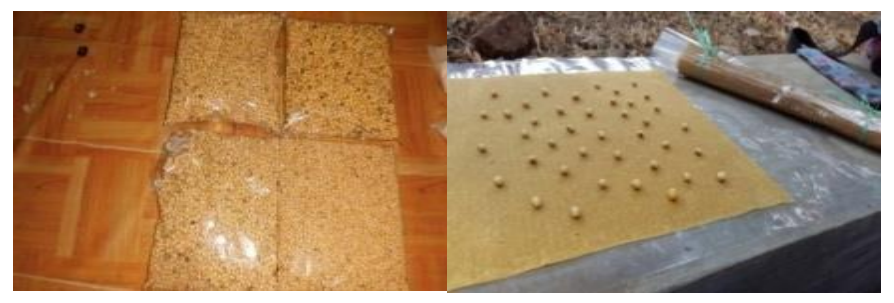

Benih dikemas $2 \mathrm{~kg} \quad$ Uji daya kecambah benih

Gambar 12. Produk Benih Kedelai Hasil Pertanaman

Total produksi keempat varietas kedelai unggul berkisar sekitar $116 \mathrm{~kg}$ dan berdasarkan hasil uji laboratorium masing-masing contoh memiliki daya kecambah benih yang cukup tinggi yaitu Gepak Kuning (92,5\%), Argomulyo (92,5\%), Mutiara1 (82,5\%), dan Dering1 $(90 \%)$, hal ini menunjukkan bahwa lahan tersebut potensial untuk memproduksi benih kedelai varietas unggul yang berkualitas.

\section{Praktik Pembuatan Tahu}

Bahan baku kedelai yang digunakan dalam kegiatan ini berasal dari hasil pertanaman mitra di lapangan dari keempat varietas yang ditanam. Berdasarkan informasi dari salah seorang perajin tahu bahwa untuk pembuatan 400 buah potongan tahu diperlukan sebanyak $6 \mathrm{~kg}$ kedelai. Proses pembuatan tahu dilakukan dengan melibatkan salah seorang perajin tahu di lokasi tersebut. Serangkaian kegiatan pembuatan tahu diikuti oleh perwakilan mitra di rumah milik perajin tahu (Gambar 13). 


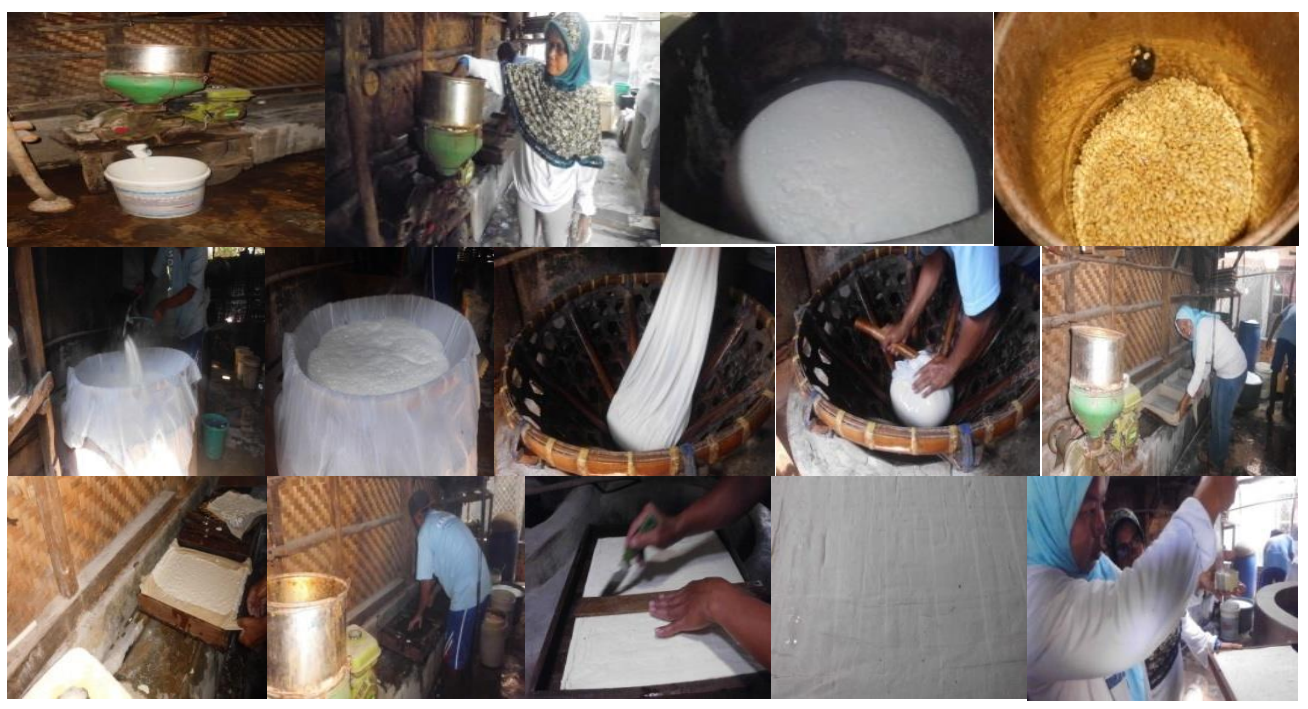

Gambar 13. Rangkaian Praktik Pembuatan Tahu Kedelai Hasil Pertanaman Mitra

\section{Kegiatan Pembinaan dan Kerjasama}

Kondisi saat ini, masyarakat umum beranggapan bahwa kedelai impor merupakan kedelai yang memiliki kualitas baik sebagai bahan baku pembuatan tahu, namun harus terus diupayakan agar tidak selalu bergantung impor. Untuk meningkatkan kepercayaan masyarakat terhadap kualitas kedelai lokal sebagai bahan baku pembuatan tahu diperlukan adanya kegiatan nyata untuk mensosialisasikan varietas unggul baru yang sudah dihasilkan oleh para peneliti.

Hasil kegiatan ini diharapkan dapat dijadikan sebagai langkah awal untuk meyakinkan bahwa kedelai unggul varietas lokal yang dihasilkan petani setempat dapat juga digunakan sebagai bahan baku tahu yang berkualitas sama halnya dengan kedelai impor. Produk tahu yang dihasilkan mitra dibagikan kepada masyarakat setempat (Gambar 14.) agar dapat dikenal kualitas kedelai lokal setelah dibuat menjadi tahu.

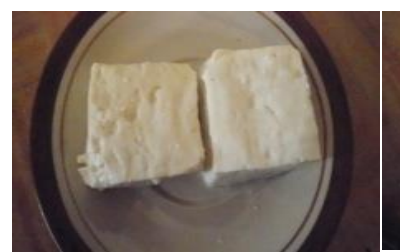

Mutiara1

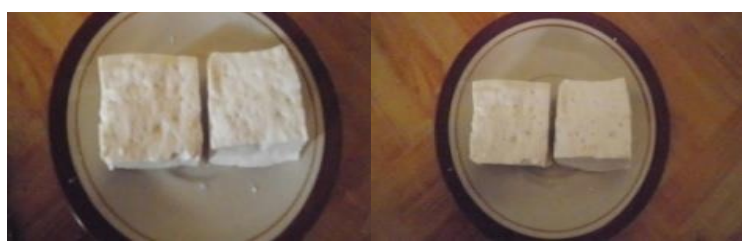

Dering1

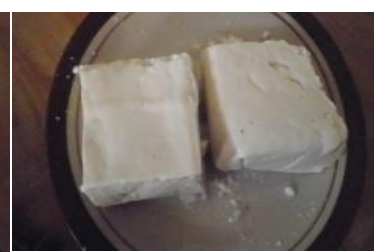

Argomulyo

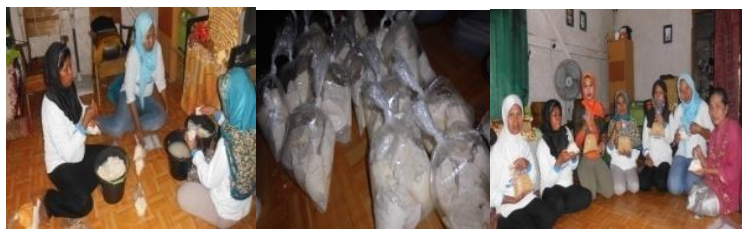

Gambar 15. Produk yang Dihasilkan 


\section{Pembinaan dan Kerjasama}

Kegiatan pendampingan harus terus dilakukan baik oleh pihak perguruan tinggi maupun petugas penyuluh lapangan dari Dinas Pertanian Kabupaten Sumedang agar benih-benih yang dihasilkan dapat kembali ditanam di daerah tersebut pada musim tanam berikutnya dan diharapkan dapat menjadi pendorong masyarakat setempat untuk menjadi penangkar benih kedelai unggul varietas-varietas unggul bersertifikat sehingga dapat memenuhi kebutuhan para petani yang membutuhkan benih unggul tersebut dan diharapkan dapat terjadi perluasan pertanaman kedelai sebagai upaya untuk mencapai swasembada kedelai khususnya untuk daerah Kabupaten Sumedang.

\section{SIMPULAN}

Berdasarkan serangkaian kegiatan yang dilakukan, menunjukkan bahwa: 1) Pertanaman kedelai varietas unggul menunjukkan pertumbuhan serta kuantitas dan kualitas benih yang baik memiliki daya kecambah $>85 \%$; 2) Mitra dapat melakukan penangkaran benih kedelai varietas unggul dengan proses sertifikasi benih; 3) Meningkatnya wawasan dan keterampilan mitra dalam budidaya kedelai serta penanganan hama penyakit di lapangan; 4) Meningkatnya kepercayaan mitra terhadap kualitas kedelai lokal yang dapat dijadikan sebagai bahan baku pembuatan tahu.

Sebagai saran, perlu adanya kerjasama berkelanjutan antara pihak Perguruan Tinggi, petani, dan pemerintahan terkait dalam mensosialisasikan dan mengembangkan varietas unggul kedelai yang berpotensi sebagai bahan baku pembuatan tahu untuk memenuhi kebutuhan kedelai masyarakat.

\section{REFERENSI}

Balitbang Pertanian. (2014). Laporan tahunan 2013: Inovasi teknologi pertanian ramah lingkungan dan berdaya saing. Jakarta: IAARD Press.

BPS. (2013). Produksi padi, jagung, dan kedelai (Angka ramalan 1 tahun 2013). Retrieved January 31, 2014 from http://www.bps.go.id/brs_file/aram_01jul13.pdf.

Direktorat Jenderal Tanaman Pangan. (2013). upaya-upaya khusus percepatan program pengembangan kedelai tahun 2013. Jakarta: Kementerian Pertanian Republik Indonesia.

Elfiani, E., \& Jakoni, J. (2017). Pengujian daya berkecambah benih dan evaluasi struktur kecambah benih. DINAMIKA PERTANIAN, 30(1), 45-52.

FAOSTAT. (2012). Database food and agriculture organization of the united nation. Retrieved January 31, 2014 from http://faostat.fao.org/site/340/DesktopDefaulth.aspx?PageID=340.

Ilyas, S. (2012). Ilmu dan teknologi benih: Teori dan hasil-hasil penelitian. Bogor: IPB Press.

Kementerian Perdagangan. (2015). Laporan akhir: Kajian efektivitas kebijakan impor produk pangan dalam rangka stabilisasi harga. Jakarta: Puska Daglu, BP2KP, Kementerian Perdagangan RI. 
Krisdiana, R. (2015). Preferensi industri tahu dan tempe terhadap ukuran dan warna biji kedelai. Iptek Tanaman Pangan, 2(1), 123-130.

Mulyani, A., Rachma, A., \& Dairah, A. (2010). Penyebaran lahan masam potensi dan ketersediaannya untuk pengembangan pertanian. Bogor: Balai Penelitian Tanah (Balittanah).

Pawiroharsono, S. (2012). The role of biotechnology for improvement of soybean production in sub-optimal land. Widyariset, 15(3), 665-672.

Sudaryanto, T., \& Swastika, D. K. (2007). Ekonomi kedelai di Indonesia. Forum Agro Ekonomi (FAE), 12(3), 1-27.

Sumarno. (2011). Membuka lahan baru "kunci untuk swasembada kedelai". Tabloid Sinar Tani, Edisi 30 Maret-5 April 2011. 